\title{
Influence of Substrates in the Development of Bean and in Pathogenicity of Rhizoctonia solani JG Kühn
}

\author{
Sara Mayo-Prieto ${ }^{1, *(\mathbb{0},}$, Álvaro Rodríguez-González ${ }^{1}{ }^{\circledR}$, Alicia Lorenzana ${ }^{1}{ }^{(0)}$, \\ Santiago Gutiérrez ${ }^{2}\left(\mathbb{D}\right.$ and Pedro A. Casquero ${ }^{1}$ (I) \\ 1 Grupo Universitario de Investigación en Ingeniería y Agricultura Sostenible (GUIIAS), \\ Instituto de Medio Ambiente, Recursos Naturales y Biodiversidad, Universidad de León, \\ Avenida Portugal 41, 24071 León, Spain; alrog@unileon.es (Á.R.-G.); alorv@unileon.es (A.L.); \\ pacasl@unileon.es (P.A.C.) \\ 2 Grupo Universitario de Investigación en Ingeniería y Agricultura Sostenible (GUIIAS), \\ Área de Microbiología, Escuela de Ingeniería Agraria y Forestal, Universidad de León, \\ Campus de Ponferrada, Avenida Astorga s/n, 24400 Ponferrada, Spain; s.gutierrez@unileon.es \\ * Correspondence: smayp@unileon.es; Tel.: +34-987-291-000 (ext. 5058)
}

Received: 2 April 2020; Accepted: 12 May 2020; Published: 15 May 2020

\begin{abstract}
The number of plants produced in horticultural substrates has increased over the last decade. These substrates are to have some physicochemical and phytosanitary characteristics that allow for optimal growth. Rhizoctonia solani JG Kühn is one of the root and hypocotyl diseases that frequently develops in seedbeds causing severe economic losses worldwide. The aim of this work was to evaluate the substrates and additives used in bean plantlets and the $R$. solani disease severity. The use of vermiculite or peat did not affect bean germination percentage, but peat promoted the development of the aerial part and vermiculite improved the growth of the root system. R. solani reduced bean germination percentage and bean growth in both peat and vermiculite. The presence of additives (bentonite and/or cornmeal) in the substrates (vermiculite or peat) reduced bean germination and development, favouring the severity of $R$. solani. However, the addition of cornmeal improves bean dry weight of the aerial part. So, whenever it is necessary to add additives to the substrates to improve the installation and development of a biocontrol agent, such as Trichoderma harzianum, the mix of peat and cornmeal would improve the development of both bean and biocontrol agent.
\end{abstract}

Keywords: additive; peat; Phaseolus vulgaris; plantlet; vermiculite

\section{Introduction}

Every day, the number of plants produced in nurseries increases and they are transplanted both for small-scale production, or self-consumption, and for large-scale production. If the desire is to produce healthy plants free of phytopathogens starting from healthy and registered seeds, a substrate that reduces their propagation and development is needed. Integrated crop health management approaches, using both modern cultivars with resistance/tolerance to these organisms and technologies that stimulate root health and growth, accompanied by chemical, biological and cultural phytopathogen management strategies are needed for sustainable production.

Some growing media may have a lower risk because of the nature of their production. They may become contaminated or infested, depending on the type and composition of the substrate during the production process [1]. Knowledge about the relationships between plants, plant pathogens and antagonists, and about the physico-chemical properties of the soil, will help control diseases, reducing the use of chemical products.

Most potting substrates are a combination of organic (peat, bark, straw, etc.) and inorganic materials (vermiculite, perlite, clay, etc.). The addition of organic compounds, such as cornmeal, improves 
properties like water retention capacity, porosity and cation exchange capacity, also acting as a nutrient source for biological control agents [2,3]. Particle size distribution also plays an important role in adequate aeration of the plant root [4] and in the water-holding capacity of the media [5]. Some changes modify the dynamics of the nutrients in the soil, changing the availability of carbon $(\mathrm{C})$, nitrogen $(\mathrm{N})$, phosphorus $(\mathrm{P})$ or sulphur (S) and therefore affecting plant growth [6,7]. Variations in soil microorganisms, soil enzymes, and soil substance turnover will also affect plant performance [8]. The use of substrate amendments, such as bentonite, increases soil water and nutrient holding capacities $[9,10]$.

Inert substrates made with clay pellets, gravels, vermiculite and perlite present a lower risk of hosting pests and pathogens in plant production, than any substrate with peat, coconut fibre, bark, compost, vermicompost, wood chips, cork or moss, all which have greater phytopathogen development [11]. Nutrient availability is an important criterion for soil-borne saprotrophic phytopathogens to become prevalent in soils. Their possible outgrowth can be constrained by nutrients, space, etc. [12-14]. Crop soils are biologically active soils, with capacity to control pathogenic infections of plants, however, this capacity is lost or reduced in the substrate of a greenhouse. The use of natural products such as organic additives is a promising alternative for managing diseases and for promoting the development of other beneficial microorganisms.

Some studies evaluate the use of additives for massive production of biocontrol agents using products such as seeds of rice and rice husk (Oryza sativa L.), wheat (Triticum spp.), sorghum (Sorghum bicolor (L.) Moench), maize and cornmeal (Zea mays L.), millet (Setaria italica (L.) Beauv.), soya bean (Glycine max (L.) Merr.), chickpea (Cicer arietinum L.), cowpea (Vigna unguiculate Engl.), sunflower (Helianthus annuus L.), peanut (Arachis hypogea (L.) R. Wilczek) and other additives such as tea waste, saw dust, coir pith, bentonite, etc. [15-19]. Studies have verified that organic additives have been effective in the management of some key soil-borne pathogens such as Fusarium spp. [20,21], Pythium spp. [22,23], Rhizoctonia sp. [24,25].

A lot of soil-borne pathogens cause root rot disease in common bean and are a major constraint to bean production world-wide. Root rot diseases cause seedling death and poor seedling emergence. Disease incidence during flowering and pod fill results in the most significant yield reductions. In common bean, the primary diseases and pathogens associated with root rot include Fusarium root rot, caused by Fusarium solani (Mart.) Sacc. f. s, phaseoli (Burkholder) W. C. Snyder and H. N. Hans; southern blight, caused by Sclerotium rolfsii Sacc; Pythium root rot, caused by several species of Pythium spp. Pringsh; Aphanomyces root rot, caused by Aphanomyces euteiches f. sp. phaseoli W.F. Pfender \& D.J. Hagedorn and f. sp. pisi W.F. Pfender \& D.J. Hagedorn, and Rhizoctonia root rot, caused by Rhizoctonia solani JG Kühn [26-29].

The last phytopathogen, R. solani (Teleomorph: Thanatephorus cucumeris (AB Frank) Donk), is a necrotrophic soil pathogen, which frequently develops in seedbeds and has a worldwide distribution that causes vast economic losses all around the globe [30-32]. R. solani attacks plants of almost any age leading to a variety of symptoms in plants $[33,34]$. Infection of the plant occurs through wounds or by the coating of an organ by the mycelium, which tears the cuticle and penetrates the epidermis. This pathogen is more aggressive at temperatures between 15 and $18^{\circ} \mathrm{C}$ and in moist soil. It causes seed rot and damping-off of seedlings, as well as stunting, yellowing, and death of younger plants. It appears in the roots and stems showing red-brown lesions which may enlarge to girdle the stem, killing roots and weakening the top of the plant. Infected plants may be stunted, and leaves may turn yellow and die [35].

Until now, mass production of biocontrol agents has been evaluated using substrates enriched with different additives. However, the effect of these additives in the development of a pathogen is unknown. It is for that reason that the aim of this work is to determine the influence of horticultural substrate and additive combinations in the development of bean plantlets and in the pathogenicity of $R$. solani. 


\section{Materials and Methods}

\subsection{Rhizoctonia Solani Isolate}

R. solani R43 was used in this study, taken from the collection of "Pathogens and Antagonists" of the Laboratory Diagnosis of Pests and Diseases (University of León, León, Spain). It is an isolate collected from the production area of the Protected Geographical Indication (PGI), called "Alubia La Bañeza-León" (EC Reg. n.256/2010 published on 26 March 2010, OJEU L880/17), without any genetic manipulation.

\subsection{Substrates and Bioassays}

Bioassays were performed in climatic chambers in order to test $R$. solani activity. Peat (Pindstrup Peat 32, Pindstrup Mosebrug S.A.E., Sotopalacios, Burgos, Spain) and vermiculite (Verlite ${ }^{\circledR}$, Vermiculita y derivados, Gijón, Spain) and their combinations with the additives cornmeal (C) (Fioretto ${ }^{\circledR}$, Biemme, Saluzzo, Italy) and bentonite (B) (Bengel ${ }^{\circledR}$, Agrovin, Ciudad Real, Spain) were tested in this bioassay and their characteristics are described in detail by Mayo-Prieto et al. [36]. Theses substrates and additives were disinfected by autoclaving at $120^{\circ} \mathrm{C}$ for $1 \mathrm{~h}$ on 2 consecutive days. Eight different treatments (combinations of substrates and additives) were evaluated using ten polypropylene pots ( $1 \mathrm{~L}$ capacity) used per treatment (Table 1 ), meaning 10 repetitions per treatment.

Table 1. Substrates and their combinations tested in order to $R$. solani pathogenicity.

\begin{tabular}{ccccccccc}
\hline \multirow{2}{*}{ Substrate } & \multicolumn{8}{c}{ Treatments } \\
\cline { 2 - 9 } & $\mathbf{1}$ & $\mathbf{2}$ & $\mathbf{3}$ & $\mathbf{4}$ & $\mathbf{5}$ & $\mathbf{6}$ & $\mathbf{7}$ & $\mathbf{8}$ \\
\hline Peat (\%) & 100 & - & 95 & - & 98 & - & 93 & - \\
Vermiculite (\%) & - & 100 & - & 95 & - & 98 & - & 93 \\
Bentonite (\%) & - & - & 5 & 5 & - & - & 5 & 5 \\
Cornmeal (\%) & - & - & - & - & 2 & 2 & 2 & 2 \\
\hline
\end{tabular}

Each pot was watered with $250 \mathrm{~mL}$ of water prior to inoculation. Each pot was inoculated with a $50 \mathrm{~mL}$ suspension of $R$. solani R43 by a surface irrigation (5 Petri dishes/water litter) [37]. For inoculation of the control, only PDA medium was used without any pathogen in all combinations of substrates and they were placed in the same climatic chamber as the substrates with the pathogen. Pots were kept in a growth chamber for 8 days at $25{ }^{\circ} \mathrm{C} / 16{ }^{\circ} \mathrm{C}$ (day/night), $60 \% \mathrm{RH}$ in the dark.

Bean seeds of "Canela" variety were surface sterilised (sodium hypochlorite $1 \%$ for 3 min and in distilled water for $6 \mathrm{~min}$ ). After 8 days of the inoculation of $R$. solani R43, three seeds were sown in each pot (10 pots/treatment). The culture was maintained for 45 days with a photoperiod of $16 \mathrm{~h}$ light, $25{ }^{\circ} \mathrm{C} / 16{ }^{\circ} \mathrm{C}$ (day/night), $60 \% \mathrm{RH}$ and brightness of 3500 lux. Irrigations were performed every 4 days with about $250 \mathrm{~mL}$ tap water/pot [37]. A nutrient solution was added on the 2nd-4th week [38].

Bean germination percentage was evaluated 12, 17 and 24 days after sowing. Plants were then removed 45 days after sowing and the following parameters were evaluated: disease severity percentage in the aerial part (1: without chlorosis; 2 : 1\%-10\% of the leaves with chlorosis; $3: 11 \%-25 \%$ of the leaves with chlorosis; $4: 26 \%-50 \%$ of the leaves with chlorosis; 5 : more of $50 \%$ of the leaves with chlorosis; 6: plant of bean without leaves; 7 : dead plant of bean; 8: dead plant after the germination), wet weight and dry weight $\left(72 \mathrm{~h}\right.$ in an oven, $\left.82^{\circ} \mathrm{C}\right)$ of the aerial part and root system.

\subsection{Statistical Analysis}

Bean germination percentage and disease severity percentage data were transformed by the formula $(x+0.5)^{1 / 2}$. Square-root transformation is appropriate for data consisting of small whole numbers, for example, data obtained in counting rare events, such as the number of infested plants in a plot and for percentage data $[39,40]$. Combined analysis of variance was performed using the general linear models (GLM). Orthogonal contrasts were used for additive to isolate treatment effects [41]. 
For the control without additive, the contrast was without additive versus cornmeal, bentonite and cornmeal-bentonite. For the additive the contrast was cornmeal-bentonite versus cornmeal and bentonite. The last contrast was cornmeal versus bentonite. All analyses were performed using SAS version 9.4 software (SAS Institute Inc., 2015, Cary, NC, USA).

\section{Results}

\subsection{Germination}

Analysis of variance shows highly significant differences in pathogen and additives for germination percentage at 12, 17 and 24 days after sowing. However, there are not significant differences between substrates for germination percentage (Table 2).

The Table 3 shows the orthogonal contrast among additives. Contrasts show highly significant differences for germination between the control and all additive combinations (control versus $\mathrm{B}+\mathrm{C}+\mathrm{BC}$ ). However, the rest of the orthogonal contrasts for germination among additives [BC versus $(B+C)$ and $B$ versus $C]$ are not significantly different (Table 3 ).

The Figure 1 shows the germination percentage and removed seeds percentage after 24 days of sowing for substrate, pathogen and additives. The two tested substrates (vermiculite and peat) do not affect the germination percentage for either removed seeds percentage. However, the pathogen, R. solani has reduced the germination compared with control, increasing the removed seeds. The addition of cornmeal and/or bentonite to the substrates has reduced the germination percentage.

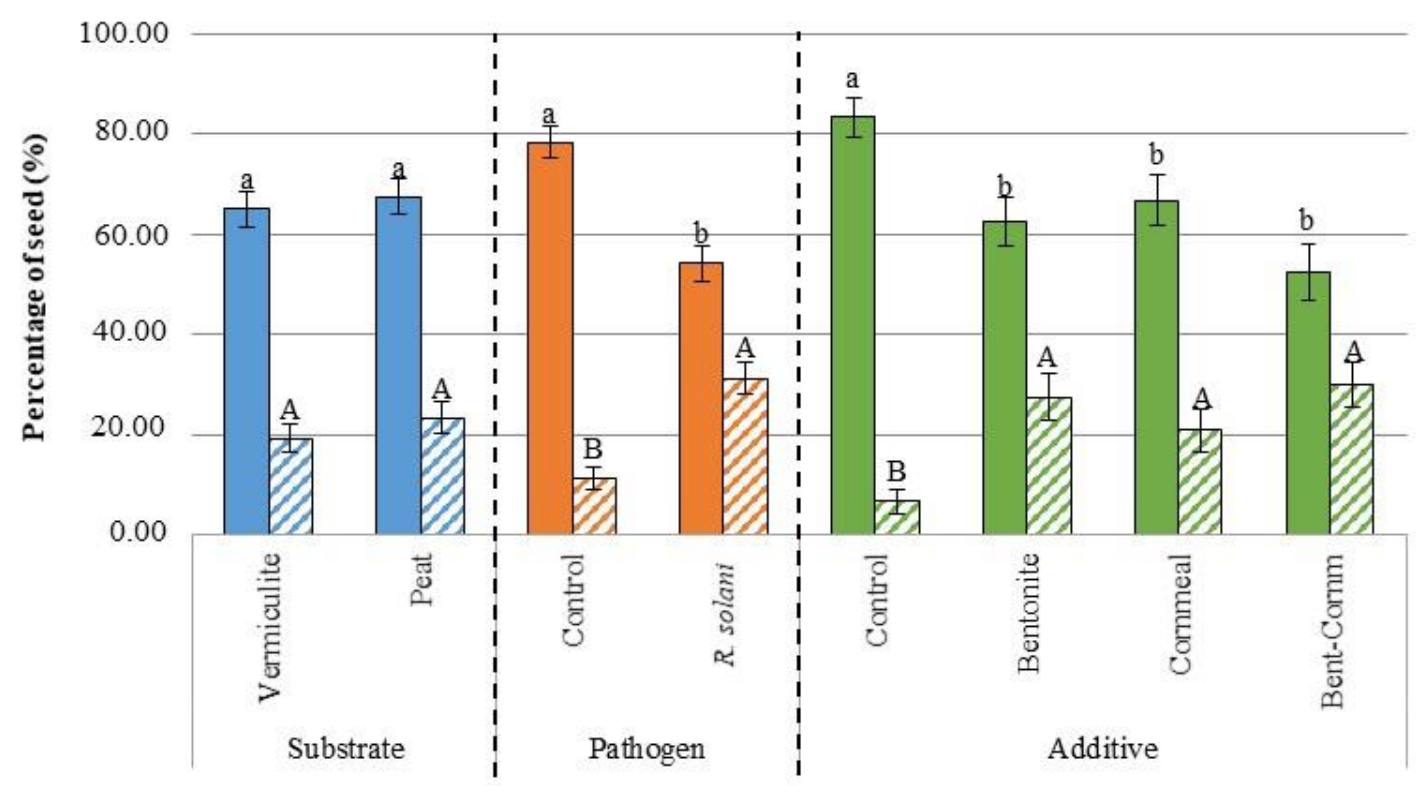

Figure 1. Germination percentage and removed seeds percentage after 24 days of sowing for substrates, pathogen and additives. Blue colour represents the substrates; orange colour represents the presence or absence of $R$. solani; green colour represents the types of additives; solid colour represents germination and with striped colour represents removed seeds. Bars of the same colour followed by different letters (small letter for germinated seeds and capital letters for removed seeds) are significantly different $(p \leq 0.01)$. 
Table 2. Means squares of the combined analyses of variance for germination in 12, 17 and 24 days after sowing, disease severity 45 days after sowing, and dry weights of aerial part and root system.

\begin{tabular}{|c|c|c|c|c|c|c|c|c|c|c|c|c|c|}
\hline \multirow{3}{*}{$\begin{array}{c}\text { Source of Variation } \\
\text { Pathogen }\end{array}$} & \multirow{3}{*}{$\begin{array}{c}\text { d.f. } \\
1\end{array}$} & \multicolumn{6}{|c|}{ Germination (\%) } & \multirow{2}{*}{\multicolumn{2}{|c|}{$\begin{array}{l}\text { Disease } \\
\text { Severity }\end{array}$}} & \multirow{2}{*}{\multicolumn{2}{|c|}{$\begin{array}{l}\text { Dry Weight } \\
\text { Aerial Part (g) }\end{array}$}} & \multirow{2}{*}{\multicolumn{2}{|c|}{$\begin{array}{c}\text { Dry Weight } \\
\text { Root System (g) }\end{array}$}} \\
\hline & & \multicolumn{2}{|c|}{ Day 12} & \multicolumn{2}{|c|}{ Day 17} & \multicolumn{2}{|c|}{ Day 24} & & & & & & \\
\hline & & $23,361.122$ & $* * *$ & $16,673.610$ & $* * *$ & $18,062.500$ & $* * *$ & 35.685 & $* * *$ & 1.071 & $* * *$ & 30.719 & $* * *$ \\
\hline Substrate & 1 & 250.001 & & 173.611 & & 173.611 & & 0.928 & & 1.200 & $* * *$ & 14.306 & $* * *$ \\
\hline Additive & 3 & 6601.854 & $* * *$ & 6081.019 & $* * *$ & 5599.536 & $* * *$ & 5.871 & $* * *$ & 0.234 & $* * *$ & 21.382 & $* * *$ \\
\hline Pathogen X Substrate & 1 & 1361.112 & & 3673.613 & * & 3062.502 & * & 0.243 & & 0.051 & & 0.026 & \\
\hline Pathogen X Additive & 3 & 1601.852 & & 729.167 & & 1081.019 & & 0.077 & & 0.029 & * & 1.683 & \\
\hline Substrate $X$ Additive & 3 & 490.741 & & 858.796 & & 673.611 & & 0.487 & & 0.078 & & 5.571 & $* * *$ \\
\hline Pathogen $X$ Substrate $X$ Additive & 3 & 1416.668 & & 469.907 & & 710.648 & & 1.459 & & 0.040 & & 3.713 & $* *$ \\
\hline
\end{tabular}

Table 3. Orthogonal contrast for additives in the parameters germination, disease severity 45 after sowing, and dry weights of aerial part and root system.

\begin{tabular}{|c|c|c|c|c|c|c|c|c|c|}
\hline \multirow{2}{*}{$\begin{array}{c}\text { Source of Variation }{ }^{1} \\
\text { Control vs. }(B+C+B C)\end{array}$} & \multirow{2}{*}{$\begin{array}{c}\text { d.f. }^{2} \\
1\end{array}$} & \multicolumn{2}{|c|}{ Germination (\%) } & \multicolumn{2}{|c|}{ Disease Severity } & \multicolumn{2}{|c|}{ Dry Weight of Aerial Part (g) } & \multicolumn{2}{|c|}{ Dry Weight of Root System (g) } \\
\hline & & $<0.0001$ & $* * *$ & $<0.0001$ & $* * *$ & 0.0020 & $* * *$ & $<0.0001$ & $* * *$ \\
\hline BC vs. $(B+C)$ & 1 & 0.3115 & & 0.0797 & & 0.2310 & & 0.0013 & $* * *$ \\
\hline B vs. C & 1 & 0.3855 & & 0.7853 & & 0.0009 & $* * *$ & 0.5666 & \\
\hline
\end{tabular}

${ }^{1}$ B: bentonite; C: Cornmeal; BC: Bentonite and cornmeal; ${ }^{2}$ Degrees of freedom; *** Significant at $p \leq 0.001$. 


\subsection{Disease Severity}

Analysis of variance shows highly significant differences in pathogen and additives for disease severity. However, there are not significant differences between substrates for disease severity (Table 2).

The Table 3 shows the orthogonal contrast among additives. Contrasts show highly significant differences for disease severity between the control and all combinations of additives (control versus $B+C+B C$ ). However, the rest of orthogonal contrast for disease severity among additives (BC versus $B+C$ and $B$ versus $C$ ) are not significantly different.

Symptomatology of the aerial part has not presented significant differences between peat and vermiculite. Nevertheless, the presence of $R$. solani in the substrate has caused an increase in the disease severity in the aerial part being significantly different to the control plants. The addition of cornmeal and/or bentonite to the substrates has increased the bean disease severity relative to the control (Figure 2).

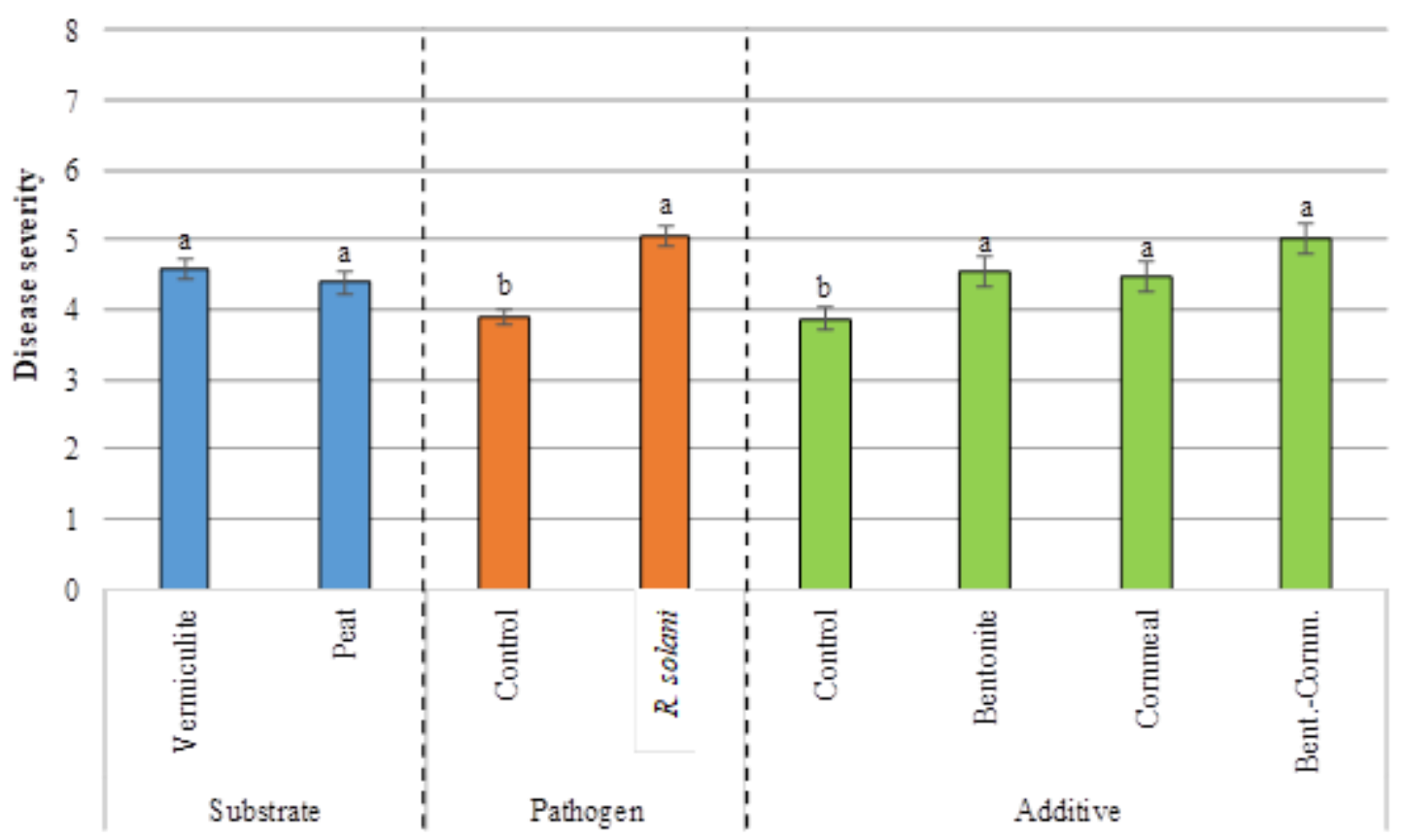

Figure 2. Disease severity in aerial part at 45 days after sowing for substrates, pathogen and additives. Disease severity scale: 1 , without chlorosis; $2,1 \%-10 \%$ of the leaves with chlorosis; $3,11 \%-25 \%$ of the leaves with chlorosis; $4,26 \%-50 \%$ of the leaves with chlorosis; 5 , more than $50 \%$ of the leaves with chlorosis; 6 , plant of bean without leaves; 7 , dead plant of bean; 8 , dead plant after the germination. Blue colour represents the substrates; orange colour represents the presence or absence of $R$. solani; green colour represents the types of additives. Bars of the same colour followed by different letters are significantly different $(p \leq 0.01)$.

\subsection{Dry Weight}

When the dry weight of the aerial part has been analysed, bean plants in peat have been significantly larger than those in vermiculite. The presence of $R$. solani has caused a decrease in the weight of the bean aerial part. In regard to the additives, the greatest bean dry weight of the aerial part was found when cornmeal was in the substrate. Bean plants grown in the substrate with bentonite and cornmeal have shown the smallest bean dry weight of the aerial part (Figure 3).

Analysis of variance shows highly significant differences in pathogens, substrates and additives for the dry weight of the bean root system (Table 2).

Orthogonal contrasts of the dry weight of the bean root system have shown highly significant differences between control and all additive combinations and between bentonite and cornmeal separately as well as bentonite and cornmeal combined ( $B C$ versus $B+C)$. However, there were not significant differences found between bentonite and cornmeal (B versus $\mathrm{C}$ ) for bean root growth (Table 3). 


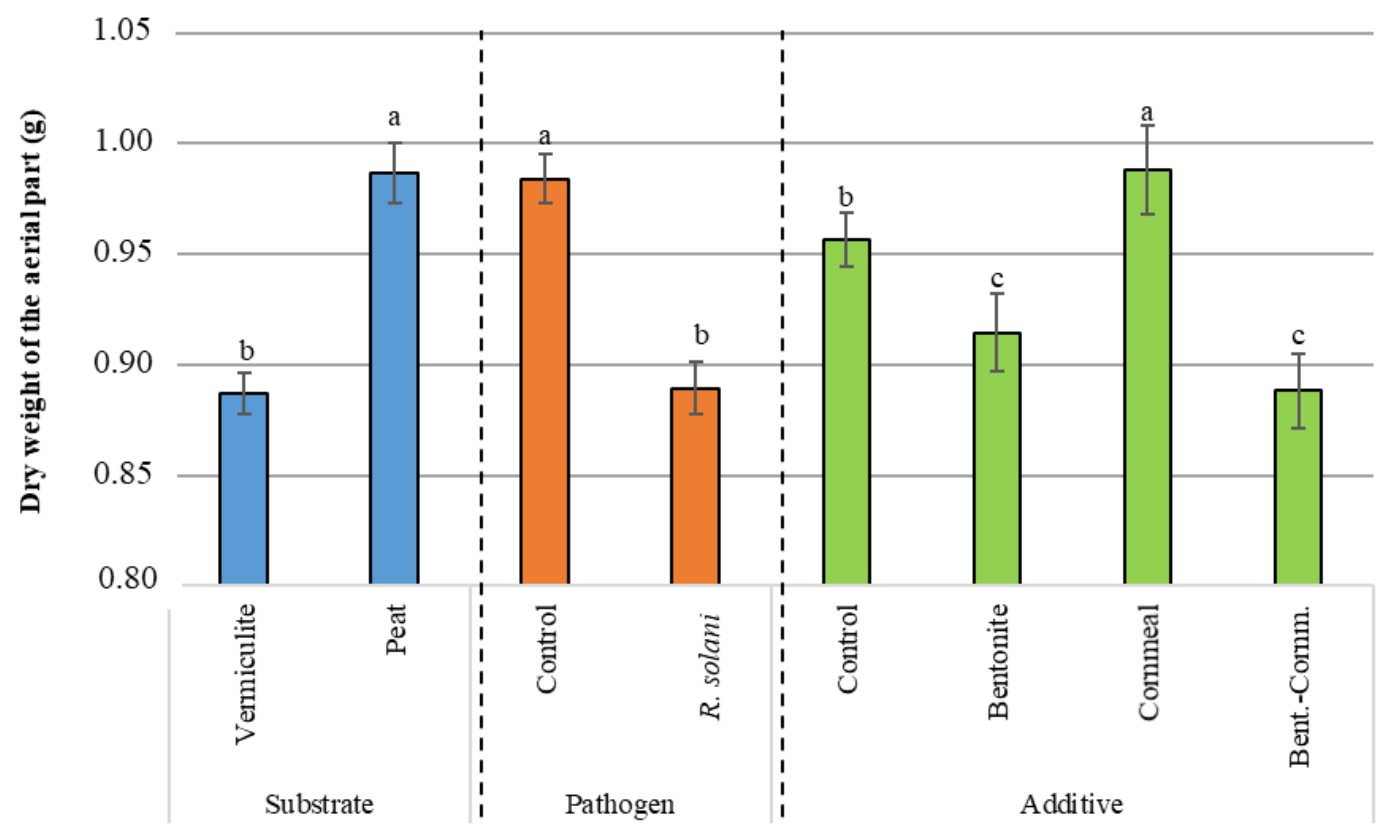

Figure 3. Dry weight of the bean aerial part for substrates, pathogen and additives. Blue colour represents the substrates; orange colour represents the presence or absence of $R$. solani; green colour represents the types of additives. Bars of the same colour followed by different letters are significantly different $(p \leq 0.01)$.

Bean plants had a significantly bigger root system in vermiculite than in peat. The presence of $R$. solani caused a decrease in the bean root weight. In regard to the additives, bean plants in substrates with additives had a significantly lower root weight than the control. Bean plants grown in the substrates with bentonite and cornmeal showed the smallest bean root weight, as well as significant differences with the control substrate and with bentonite or cornmeal separately (Figure 4).

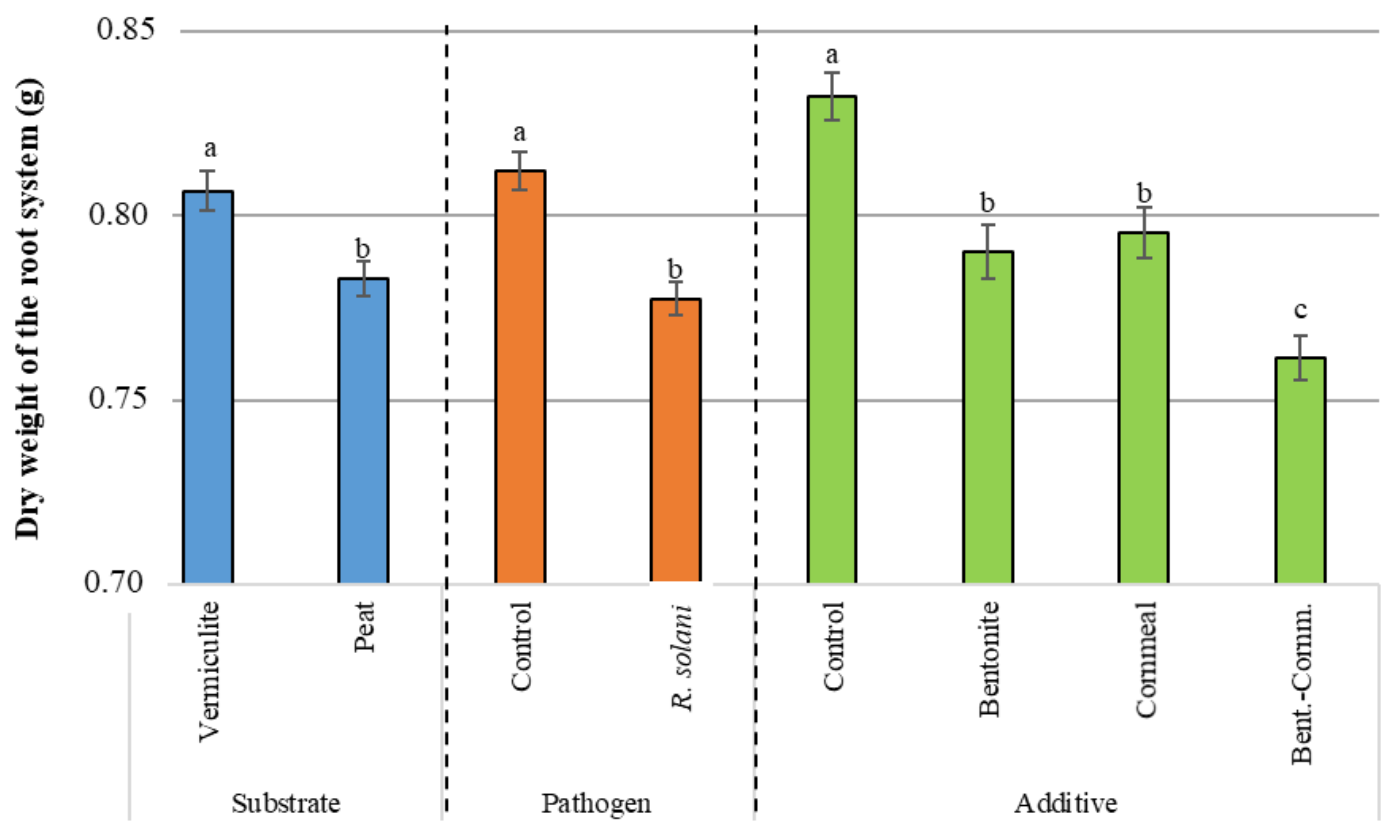

Figure 4. Dry weight of the bean root system for substrates, pathogen and additives. Blue colour represents the substrates; orange colour represents the presence or absence of $R$. solani; green colour represents the types of additives. Bars of the same colour followed by different letters are significantly different $(p \leq 0.01)$. 


\section{Discussion}

In horticulture, a lot of plants are produced in mineral and organic substrates. This market is directed towards the pursuit of a substrate that produces healthy plants without the need for any synthetic plant protection chemicals. For that reason, the search for combinations of substrates and additives is important to achieve this goal. A problem is that different substrates can promote not only the development of the plant, but also the growth of beneficial or harmful organisms. Soil-borne plant pathogens infecting plant roots are one of the biggest problems the world of agriculture faces because of the reduction in yield and quality of the crops. An example of one of these phytopathogens is $R$. solani which causes an economically harmful disease on a range of agricultural crops [42]. This study has evaluated the development of bean plants in substrates with different additives and how they affect this pathogen that can decrease bean production between $5 \%$ and $60 \%[43,44]$. Results show that $R$. solani caused a reduction in germination compared to the control. This is because the bean seeds and young bean plants are more susceptible to it than adult plants [35]. Adult plants suffered a reduction in the production of dry matter with the aerial part and the root system having developed less than those of control plants. In others works, bean plants inoculated with $R$. solani have also had a significative reduction in their growth $[37,45]$.

In our study, the interaction between pathogen and substrate has not been significative in disease severity, indicating that neither peat nor vermiculite have modified the development of the bean plant or the symptoms produced by R. solani. In the work of Cohen et al. [46] they observed that the incidence of the disease caused by Fusarium oxysporum f. sp. melonis in melon plants was higher in plants grown in peat or peat mixed with sand than in those developed in a combination of peat and pearlite. In another study, Campelo et al. [47] studied the effect of Sclerotinia sclerotiorum and R. solani in bean plants sown in vermiculite where the first pathogen reduced the development but Rhizoctonia presented low pathogenicity both in the aerial part and in the root system.

$R$. solani as pathogenic fungi, are particularly sensitive to certain management practices, such as fertilization, and the C contents [48]. Harries et al. [49] studied some tobacco soil and its influence in the development of $R$. solani. They determined that high levels of clay, $\mathrm{pH}$, organic matter content and physical stability were associated with low $R$. solani inoculum potential in tobacco soils. It has been observed that suppression of $R$. solani growth is negatively correlated to $\mathrm{pH}$. A range in soil $\mathrm{pH}$ of 4.5-6.5 appears optimal for mycelial growth of $R$. solani which produces damping-off [49-51]. In our work, the $\mathrm{pH}$ of the substrates varied between 5 and 7 , so this range could have promoted the development of the $R$. solani, increasing its pathogenicity. The extent and rate of fungal growth may also depend on the soil porosity limiting the spread of the hyphae of a phytopathogen when the space is restricted [52,53], but developing rapidly in porous sandy soil [54].

Moreover, adding cornmeal to the substrate promoted $R$. solani development because of it acted as a source of carbohydrates, increasing the $C$ concentration, like it does in fields with the remains of vegetable matter. For example, when cereal or leguminous flours were incorporated to the substrate mixture, they increased the production of Penicillium conidia [55]. However, in another study, high organic matter and clay contents have also been related to soil suppression of Fusarium or Pythium [56,57].

The presence of an inoculum of a phytopathogen, a susceptible host and certain environmental conditions (soil, temperature, humidity, etc.) are all necessary for an infection [58]. One way to control of this process is practicing crop rotation, where a resistant/tolerant plant is sown, reducing the amount of inoculum. Another way to achieve this is modifying the soil or substrate in a way that favours the development of biocontrol agents. For this, biocontrol agents can be added to the substrate mixture. If a substrate is enriched with additives that provide a source of energy for the development of beneficial organisms, it will reduce the use of synthetic chemical products, therefore producing safer foods for the consumer and for the environment. In substrates with cornmeal, Trichoderma has shown higher rates of development than without this additive. Moreover, its growth has been higher whenever it has been inoculated into a mixture with peat and not vermiculite [36]. There are some studies where the use of additives has promoted the development of both the plant and Trichoderma. 
Martinez-Media et al. [15] checked that the formulation with bentoniteand vermiculite and Trichoderma was effective in enhancing plant growth and reducing the incidence of Fusarium wilt in melon plants. In another work, Bernal-Vicente et al. [16] tested some formulations with Trichoderma as liquids with spore suspension, guar gum or carboxymethylcellulose, and solids with bentonite, vermiculite and wheat bran; they verified that substrates with bentonite and vermiculite were the most effective treatments against Fusarium wilt on melon plants and resulted in the greatest plant weight.

In this study, the selection of these concentrations for bentonite (5\%) and cornmeal (2\%) is a result of a previous work, where the variations of these additives changed the development of bean plants. When these concentrations were increased, bean plants had a stunted development of both the aerial part and the root, promoting the development of saprophytic fungus and bacteria in the substrates and increasing their compaction (unpublished data).

The aerial part of the plants developed more in peat than in vermiculite, while the radicular system was greater in vermiculite than in peat. In this study, the incorporation of additives provided greater consistency and hardness to the substrate, reducing bean germination. Undoubtedly, the addition of additives caused significant differences in the development of the plant. The aerial part developed more with cornmeal than with bentonite or with both. This did not happen in the case of the root system, where all additives caused a significant reduction in its dry weight.

MacNish [59] found that compaction of soil had no effect on dry root weights of wheat plants grown for 21 days, but higher levels of compaction following the mixing of soils decreased the dry root weights of the plants. The reasons for this behaviour have not been explained through experimental data but it has been suggested that factors such as release of nutrients, changes in gas exchange or changes in microbiological activities are possible causes of this behaviour [54].

A non-autoclaved substrate has microbiota that counter the effects of a pathogen. Adding additives promotes the development of microorganisms, both pathogenic and not pathogenic. Biological agents restrict the development of a phytopathogen. Therefore, it is convenient to add not only additives but also biocontrol agents to the substrates in order to favour their installation and to control its pathogens. For example, bean seeds coated with Trichoderma and in a substrate with additives (bentonite and cornmeal) did not decrease their size in the presence of $R$. solani [37]. Nevertheless, it is important to keep in mind that additives used to promote the development of biocontrol agents may also affect the growth of some pathogens and some crops.

\section{Conclusions}

Bean germination percentage was not affected by the use of either vermiculite or peat, but peat promoted the development of the aerial part and vermiculite improved the growth of the root system. $R$. solani reduced bean germination percentage and bean growth in both peat and vermiculite. The presence of additives (bentonite and/or cornmeal) in the substrates (vermiculite or peat) reduced bean germination and root development, favouring the severity of $R$. solani. However, the addition of cornmeal improved bean dry weight of the aerial part. Therefore, whenever it is necessary to use additives in the substrates to improve the installation and development of a biocontrol agent, such as T. harzianum [36], the mix of peat and cornmeal would improve the development of both the bean and biocontrol agent.

Author Contributions: Conceptualization, S.M.-P., S.G. and P.A.C.; methodology, S.M.-P., S.G. and P.A.C.; investigation, S.M.-P., A.L. and Á.R.-G.; writing-original draft preparation, S.M.-P. and Á.R.-G.; writing-Review and editing, S.M.-P., P.A.C. and A.L.; supervision, S.G. and P.A.C.; funding acquisition, P.A.C. All authors have read and agreed to the published version of the manuscript.

Funding: This research was funded by Junta de Castilla y León, Consejería de Educación for the project "Application of Trichoderma strains in sustainable quality bean production" (LE251P18).

Conflicts of Interest: The authors declare no conflict of interest. The funders had no role in the design of the study; in the collection, analyses, or interpretation of data; in the writing of the manuscript, or in the decision to publish the results. 


\section{References}

1. Food and Agriculture Organization (FAO). IPPC ISPM 40 International movement of growing media in association with plants for planting. In International Standards for Phytosanitary Measures; FAO: Roma, Italy, 2017.

2. Dodd, S.L.; Hill, R.A.; Stewart, A. A duplex-PCR bioassay to detect a Trichoderma virens biocontrol isolate in non-sterile soil. Soil Biol. Biochem. 2004, 36, 1955-1965. [CrossRef]

3. Lima, L.K.S.; De Jesus, O.N.; Soares, T.L.; De Oliveira, S.A.S.; Haddad, F.; Girardi, E.A. Water deficit increases the susceptibility of yellow passion fruit seedlings to Fusarium wilt in controlled conditions. Sci. Hortic. (Amst.) 2019, 243, 609-621. [CrossRef]

4. Kaderabek, L.E.; Jackson, B.E.; Fonteno, W.C. Changes in the physical, chemical, and hydrologic properties of pine bark over twelve months of aging. Acta Hortic. 2017, 1174, 313-318. [CrossRef]

5. Caron, J.; Michel, J.C. Overcoming physical limitations in alternative growing media with and without peat. In Acta Horticulturae; International Society for Horticultural Science: Leuven, Belgium, 2017; Volume 1168, pp. 413-422.

6. Bowles, T.M.; Acosta-Martínez, V.; Calderón, F.; Jackson, L.E. Soil enzyme activities, microbial communities, and carbon and nitrogen availability in organic agroecosystems across an intensively-managed agricultural landscape. Soil Biol. Biochem. 2014, 68, 252-262. [CrossRef]

7. Burke, D.J.; Weintraub, M.N.; Hewins, C.R.; Kalisz, S. Relationship between soil enzyme activities, nutrient cycling and soil fungal communities in a northern hardwood forest. Soil Biol. Biochem. 2011, 43, 795-803. [CrossRef]

8. Li, Y.; Niu, W.; Zhang, M.; Wang, J.; Zhang, Z. Artificial soil aeration increases soil bacterial diversity and tomato root performance under greenhouse conditions. Land Degrad. Dev. 2020. [CrossRef]

9. Paradelo, R.; Basanta, R.; Barral, M.T. Water-holding capacity and plant growth in compost-based substrates modified with polyacrylamide, guar gum or bentonite. Sci. Hortic. (Amst.) 2019, 243, 344-349. [CrossRef]

10. Owen, J.S., Jr.; Warren, S.L.; Bilderback, T.E.; Albano, J.P. Phosphorus rate, leaching fraction and substrate influence on influent quantity, effluent nutrient content and response of a containerized woody ornamental crop. HortScience 2008, 43, 906-912. [CrossRef]

11. Puértolas, A.; Boa, E.; Bonants, P.J.M.; Woodward, S. Survival of Phytophthora cinnamomi and Fusarium verticillioides in commercial potting substrates for ornamental plants. J. Phytopathol. 2018, 166, 484-493. [CrossRef]

12. Termorshuizen, A.J.; Van Rijn, E.; Van der Gaag, D.J.; Alabouvette, C.; Chen, Y.; Lagerlöf, J.; Malandrakis, A.A.; Paplomatas, E.J.; Rämert, B.; Ryckeboer, J.; et al. Suppressiveness of 18 composts against 7 pathosystems: Variability in pathogen response. Soil Biol. Biochem. 2006, 38, 2461-2477. [CrossRef]

13. Hoitink, H.; Boehm, M. Biocontrol within the context of soil microbial communities: A substrate-dependent phenomenon. Annu. Rev. Phytopathol. 1999, 37, 427-446. [CrossRef] [PubMed]

14. Van Overbeek, L.S.; Senechkin, I.V.; Van Bruggen, A.H.C. Variation in microbial responses and Rhizoctonia solani AG2-2IIIB growth in soil under different organic amendment regimes. Can. J. Plant Pathol. 2012, 34, 268-276. [CrossRef]

15. Martínez-Medina, A.; Roldán, A.; Pascual, J.A. Performance of a Trichoderma harzianum bentonite-vermiculite formulation against Fusarium wilt in seedling nursery melon plants. HortScience 2009, 44, 2025-2027. [CrossRef]

16. Bernal-Vicente, A.; Ros, M.; Pascual, J.A. Increased effectiveness of the Trichoderma harzianum isolate T-78 against Fusarium wilt on melon plants under nursery conditions. J. Sci. Food Agric. 2009, 89, 827-833. [CrossRef]

17. Rini, C.R.; Sulochana, K.K. Substrate evaluation for multiplication of Trichoderma spp. J. Trop. Agric. 2007, 45, 58-60.

18. Ramanujam, R.; Prasad, R.D.; Sriram, S.; Rangeswaran, R. Mass production, formulation, quality control and delivery of Trichoderma for plant disease management. J. Plant Prot. Sci. 2010, 2, 1-8.

19. Chaves-Gómez, J.L.; Cotes-Prado, A.M.; Gómez-Caro, S.; Restrepo-Díaz, H. Physiological response of cape gooseberry seedlings to two organic additives and their mixture under inoculation with Fusarium oxysporum f. sp. physali. HortScience 2020, 55, 55-62.

20. Klein, E.; Katan, J.; Gamliel, A. Soil suppressiveness to Fusarium disease following organic amendments and solarization. Plant Dis. 2011, 95, 1116-1123. [CrossRef]

21. Alabouvette, C. Fusarium wilt suppressive soils: An example of disease-suppressive soils. Australas. Plant Pathol. 1999, 28, 57-64. [CrossRef] 
22. McKellar, M.E.; Nelson, E.B. Compost-induced suppression of Pythium damping-off is mediated by fatty-acid-metabolizing seed-colonizing microbial communities. Appl. Environ. Microbiol. 2003, 69, 452-460. [CrossRef]

23. Bonanomi, G.; Antignani, V.; Capodilupo, M.; Scala, F. Identifying the characteristics of organic soil amendments that suppress soilborne plant diseases. Soil Biol. Biochem. 2010, 42, 136-144. [CrossRef]

24. Diab, H.G.; Hu, S.; Benson, D.M. Suppression of Rhizoctonia solani on impatiens by enhanced microbial activity in composted swine waste-amended potting mixes. Phytopathology 2003, 93, 1115-1123. [CrossRef] [PubMed]

25. Mazzola, M. Mechanisms of natural soil suppressiveness to soilborne diseases. Antonie Leeuwenhoek 2002, 81, 557-564. [CrossRef] [PubMed]

26. Porch, T.G.; Valentin, S.; Estevez de Jensen, C.; Beaver, J.S. Identification of soil-borne pathogens in a common bean root rot nursery in Isabela, Puerto Rico. J. Agric. Univ. Puerto Rico 2014, 98, 1-14.

27. Gullino, M.L.; Gilardi, G.; Bertetti, D.; Garibaldi, A. Emerging soilborne pathogens and trends in their management. Acta Hortic. 2020, 1270, 9-21. [CrossRef]

28. Jacobs, J.L.; Kelly, J.D.; Wright, E.M.; Varner, G.; Chilvers, M.I. Determining the soilborne pathogens associated with root rot disease complex of dry bean in Michigan. Plant Health Prog. 2019, 20, 122-127. [CrossRef]

29. Torres, S.V.; Vargas, M.M.; Godoy-Lutz, G.; Porch, T.G.; Beaver, J.S. Isolates of Rhizoctonia solani can produce both web blight and root rot symptoms in common bean (Phaseolus vulgaris L.). Plant Dis. 2016, 100, 1351-1357. [CrossRef]

30. Nerey, Y.; Pannecoucque, J.; Hernandez, H.P.; Diaz, M.; Espinosa, R.; De Vos, S.; Van Beneden, S.; Herrera, L.; Höfte, M. Rhizoctonia spp. causing root and hypocotyl rot in Phaseolus vulgaris in Cuba. J. Phytopathol. 2010, 158, 236-243. [CrossRef]

31. Peña, P.A.; Steadman, J.R.; Eskridge, K.M.; Urrea, C.A. Identification of sources of resistance to damping-off and early root/hypocotyl damage from Rhizoctonia solani in common bean (Phaseolus vulgaris L.). Crop Prot. 2013, 54, 92-99. [CrossRef]

32. Guerrero-González, M.L.; Rodríguez-Kessler, M.; Rodríguez-Guerra, R.; González-Chavira, M.; Simpson, J.; Sánchez, F.; Jiménez-Bremont, J.F. Differential expression of Phaseolus vulgaris genes induced during the interaction with Rhizoctonia solani. Plant Cell Rep. 2011, 30, 1465-1473. [CrossRef]

33. Ajayi-Oyetunde, O.O.; Bradley, C.A. Rhizoctonia solani: Taxonomy, population biology and management of Rhizoctonia seedling disease of soybean. Plant Pathol. 2018, 67, 3-17. [CrossRef]

34. De Melo, M.P.; Cabral, C.S.; Reis, A.; Matos, K.S.; Martins, P.P.; Beserra Júnior, J.E.A.; Nechet, K.L.; Halfeld-Vieira, B.A. Rhizoctonia solani AG 1-IB and AG 4 HG-I causing leaf blight and root rot in plants from the Lamiaceae family in Brazil. Trop. Plant Pathol. 2018, 43, 152-159. [CrossRef]

35. Hagedorn, D.J. Rhizoctonia root rot. In Compendium of Bean Diseases; Hall, R., Ed.; American Phytopathological Society (APS): Saint Paul, MN, USA, 1991; p. 13.

36. Mayo-Prieto, S.; Porteous-Álvarez, A.J.; Rodríguez-González, Á.; Gutiérrez, S.; Casquero, P.A. Evaluation of substrates and additives to Trichoderma harzianum development by qPCR quantification. Agron. J. 2020. [CrossRef]

37. Mayo, S.; Gutierrez, S.; Malmierca, M.G.; Lorenzana, A.; Campelo, M.P.; Hermosa, R.; Casquero, P.A. Influence of Rhizoctonia solani and Trichoderma spp. in growth of bean (Phaseolus vulgaris L.) and in the induction of plant defense-related genes. Front. Plant Sci. 2015, 6, 685. [CrossRef]

38. Rigaud, J.R.; Puppo, A. Indole 3 acetic acid catabolism by soybean bacteroids. J. Gen. Microbiol. 1975, 88, 223-228. [CrossRef]

39. Gomez, A.A.; Gomez, K.A. Statistical Procedures for Agricultural Research, 2nd ed.; John Wiley \& Sons: Hoboken, NJ, USA, 1984; Volume 6, ISBN 978-0-471-87092-0.

40. Valenciano, J.B.; Casquero, P.A.; Boto, J.A.; Marcelo, V. Evaluation of the occurrence of root rots on bean plants (Phaseolus vulgaris) using different sowing methods and with different techniques of pesticide application. N. Z. J. Crop Hortic. Sci. 2006, 34, 291-298. [CrossRef]

41. Steel, R.; Torrie, J.H. Bioestadística. Principios y Procedimientos; McGraw Hill Latinomamericana: Bogotá, Colombia, 1985; Volume 2.

42. Anderson, J.P.; Lichtenzveig, J.; Oliver, R.P.; Singh, K.B. Medicago truncatula as a model host for studying legume infecting Rhizoctonia solani and identification of a locus affecting resistance to root canker. Plant Pathol. 2013, 62, 908-921. [CrossRef] 
43. Icishahayo, D.; Sibiya, J.; Dimbi, S.; Madakadze, I.C.; Manyangarirwa, W.; Chipindu, B.; Tenywa, J.S.; Joubert, G.D.; Marais, D.; Rubaihayo, P.R. Assessment of quality and health of field bean seeds home-saved by smallholder farmers. In Proceedings of the 9th African Crop Science, Conference Proceedings, Cape Town, South Africa, 28 September-2 October 2009; pp. 609-615.

44. Ahmadzadeh, M.; Sharifi Tehrani, A. Evaluation of fluorescent pseudomonads for plant growth promotion, antifungal activity against Rhizoctonia solani on common bean, and biocontrol potential. Biol. Control 2009, 48, 101-107. [CrossRef]

45. Mayo, S.; Cominelli, E.; Sparvoli, F.; González-López,O.; Rodríguez-González, A.; Gutiérrez, S.; Casquero, P.A. Development of a qPCR strategy to select bean genes involved in plant defense response and regulated by the Trichoderma velutinum-Rhizoctonia solani interaction. Front. Plant Sci. 2016, 7, 1109. [CrossRef]

46. Cohen, R.; Burger, Y.; Horev, C.; Saar, U.; Raviv, M. Peat in the inoculation medium induces Fusarium susceptibility in melons. Plant Breed. 2008, 127, 424-428. [CrossRef]

47. Campelo, M.P.; Casado, R.A.; Lorenzana, A.; Casquero, P.A.; Reinoso, B.; González, A.J. Patogenicidad de aislamientos locales de Botrytis cinerea, Rhizoctonia solani, Sclerotinia sclerotiorum y Trichothecium roseum sobre tres variedades de alubia de León. In Proceedings of the XV Congreso Nacional de la Sociedad Española de Fitopatología, Vitoria, España, 27 September-1 October 2010; p. 181.

48. Minoshima, H.; Jackson, L.E.; Cavagnaro, T.R.; Sánchez-Moreno, S.; Ferris, H.; Temple, S.R.; Goyal, S.; Mitchell, J.P. Soil food webs and carbon dynamics in response to conservation tillage in California. Soil Sci. Soc. Am. J. 2007, 71, 952-963. [CrossRef]

49. Harries, E.; Berruezo, L.A.; Galván, M.Z.; Rajal, V.B.; Mercado Cárdenas, G.E. Soil properties related to suppression of Rhizoctonia solani on tobacco fields from northwest Argentina. Plant Pathol. 2020, 69, 77-86. [CrossRef]

50. Van Agtmaal, M.; Straathof, A.L.; Termorshuizen, A.; Lievens, B.; Hoffland, E.; De Boer, W. Volatile-mediated suppression of plant pathogens is related to soil properties and microbial community composition. Soil Biol. Biochem. 2018, 117, 164-174. [CrossRef]

51. Watanabe, K.; Matsui, M.; Honjo, H.; Becker, J.O.; Fukui, R. Effects of soil pH on Rhizoctonia damping-off of sugar beet and disease suppression induced by soil amendment with crop residues. Plant Soil 2011, 347, 255-268. [CrossRef]

52. Anees, M.; Edel-Hermann, V.; Steinberg, C. Build up of patches caused by Rhizoctonia solani. Soil Biol. Biochem. 2010, 42, 1661-1672. [CrossRef]

53. Otten, W.; Gilligan, C.A. Soil structure and soil-borne diseases: Using epidemiological concepts to scale from fungal spread to plant epidemics. Eur. J. Soil Sci. 2006, 57, 26-37. [CrossRef]

54. Gill, J.S.; Sivasithamparam, K.; Smettem, K.R.J. Soil types with different texture affects development of Rhizoctonia root rot of wheat seedlings. Plant Soil 2000, 221, 113-120. [CrossRef]

55. Larena, I.; Melgarejo, P.; De Cal, A. Production, survival, and evaluation of solid-substrate inocula of Penicillium oxalicum, a biocontrol agent against Fusarium wilt of tomato. Phytopathology 2002, 92, 863-869. [CrossRef]

56. Ghini, R.; Fortes, N.L.P.; Navas-Cortés, J.A.; Silva, C.A.; Bettiol, W. Combined effects of soil biotic and abiotic factors, influenced by sewage sludge incorporation, on the incidence of corn stalk rot. PLOS ONE 2016, 11, e0155536. [CrossRef]

57. Löbmann, M.T.; Vetukuri, R.R.; de Zinger, L.; Alsanius, B.W.; Grenville-Briggs, L.J.; Walter, A.J. The occurrence of pathogen suppressive soils in Sweden in relation to soil biota, soil properties, and farming practices. Appl. Soil Ecol. 2016, 107, 57-65. [CrossRef]

58. Baker, R. Mechanisms of biological control of soil-borne pathogens. Annu. Rev. Phytopathol. 1968, 6, $263-294$. [CrossRef]

59. MacNish, G.C. The use of undisturbed soil cores to study methods of controlling Rhizoctonia patch of cereals. Plant Pathol. 1984, 33, 355-359. [CrossRef]

(C) 2020 by the authors. Licensee MDPI, Basel, Switzerland. This article is an open access article distributed under the terms and conditions of the Creative Commons Attribution (CC BY) license (http://creativecommons.org/licenses/by/4.0/). 